\title{
Teori Belajar Perenialisme
}

\author{
RAJA LOTTUNG SIREGAR \\ Sekolah Tinggi Agama Islam (STAI) Tuanku Tambusai Pasir Pengaraian \\ Jl. Riau, Pasir Pengaraian, Rokan Hulu. Hp: 081371576057 \\ e-mail: rasyi.sire83@yahoo.com
}

\begin{abstract}
Abstrak: Perenialisme, sesuai dengan namanya yang berarti segala sesuatu yang ada sepanjang sejarah, melihat bahwa teradisi perkembangan intelektual yang ada pada zaman yunani kuno dan abad pertengahan yang telah terbukti dapat memberikan solusi bagi berbagai problem kehidupan masyarakat perlu digunakan dan diterapkan dalam menghadapi alam modern yang sarat dengan problem kehidupan. Dalam hal pendidikan, perenialisme memandang bahwa tujuan utama pendidikan adalah untuk membantu siswa dalam memperoleh dan merealisasikan kebenaran abadi. Aliran ini menilai bahwa kebenaran itu bersifat universal dan konstan. Maka jalan untuk mencapainya adalah melatih intelek dandisiplin mental. Tujuan pendidikan tersebut terurai dalam format kurikulum yang berpusat pada materi (contend based, subject-centered) dan mengutamakan disiplin ilmu sastra, matematika, bahasa, humaniora, sejarah dan lain-lain.
\end{abstract}

Kata Kunci: Teori, Belajar, Perenialisme

\section{PENDAHULUAN}

Di zaman kehidupan modern ini banyak menimbulkan krisis diberbagai bidang kehidupan manusia, terutama dalam bidang pendidikan. Untuk mengembalikan keadaan krisis ini, maka perenialisme memberikan jalan keluar yaitu berupa kembali kepada kebudayaan masa lampau yang dianggap cukup ideal dan teruji ketangguhannya. Untuk itulah pendidikan harus lebih banyak mengarahkan pusat perhatiannya kepada kebudayaan ideal yang telah teruji dan tangguh. Perenialisme memandang pendidikan harus lebih banyak mengarahkan pusat perhatiannya kepada kebudayaan ideal yang telah teruji dan tangguh. Dengan kata lain pendidikan yang ada sekarang ini perlu kembali kepada masa lampau, karena dengan mengembalikan keadaan masa lampau ini, kebudayaan yang dianggap krisis ini dapat teratasi melalui perenialisme karena ia dapat mengarahkan pusat perhatiannya pada pendidikan zaman dahulu dengan sekarang.

Perenialisme memandang pendidikan itu sebagai jalan kembali yaitu sebagai suatu proses mengembalikan kebudayaan sekarang (zaman modern) in terutama pendidikan zaman sekarang ini perlu dikembalikan kemasa lampau. Perenialisme merupakan aliran filsafat yang susunannya mempunyai kesatuan, dimana susunannya itu merupakan hasil pikiran yang memberikan kemungkinan bagi seseorang untuk 
bersikap yang tegas dan lurus. Karena itulah perenialisme berpendapat bahwa mencari dan menemukan arah tujuan yang jelas merupakan tugas yang utama dari filsafat khususnya filsafat pendidikan.

Setelah perenialisme menjadi terdesak karena perkembangan politik industri yang cukup berat timbulah usaha untuk bangkit kembali, dan perenialisme berharap agar manusia kini dapat memahami ide dan cita filsafatnya yang menganggap filsafat sebagai suatu asas yang komprehensif Perenialisme dalam makna filsafat sebagai satu pandangan hidup yang berdasarkan pada sumber kebudayaan dan hasil-hasilnya.

\section{Perenialisme Dalam Pengertian dan Sejarah}

Perenialisme berasal dari kata perennial diartikan sebagai continuing throughout the whole year atau lasting for e very long time, yakni abadi atau kekal dan dapat berarti pula tiada akhir. Dengan demikian, esensi kepercayaan filsafat perenial ialah berpegang pada nilai-nilai atau normanorma yang bersifat abadi. Aliran ini mengambil analogi realiata social budaya manusia, seperti realita sepohon bunga yang terus menerus mekar dari musim ke musim,datang dan pergi, berubah warna secara tetap sepanjang masa, dengan gejala yang terus ada dan sama. Jika gejala dari musim ke musim itu dihubungkan satu dengan yang lainnya seolah-olah merupakan benang dengan corak warna yang khas, dan terus menerus sama (Djumransjah, 2006: 185-186).

Dalam pengertiannya yang lebih umum dapat dikatakan bahwa tradisi dipandang juga sebagai prinsip-prinsip yang abadi yang terus mengalir sepanjang sejarah manusia, karena ini adalah anugrah Tuhan pada semua manusia dan memang merupakan hakikat insaniah manusia (Muhmidayeli, 2005: 173).

Karena esensi aliran ini berupaya menerapkan nilai-nilai atau normanorma yang bersifat kekal dan abadi yang selalu seperti itu sepanjang sejarah manusia, maka prenialisme dianggap sebagai suatu aliran yang ingin kembali atau mundur kepada nilai-nilai keudayaan masa lampau. Kembali kepada masa lampau dalam konteks aliran ini, bukanlah dalam pengertian bernostalgia dan sekedar mengingat-ingat kembali pola kehidupan masa lalu,tetapi untuk membina kembali keyakinan akan nilainilai asasi masa silam untuk menghadapi problema kehidupan manusia saat sekarang dan bahkan sampai kapan pun dan di mana pun (Syam, 1998: 295-297). Dengan demikian maka prenialisme ini menginginkan bahwa budaya, adat istiadat-istiadat yang terbiasa mereka lakukan merupakan suatu yang abadi, kekal tanpa akhir.

Aliran perenialisme beranggapan bahwa pendidikan harus didasari oleh nilai-nilai cultural masa lampau, regressive road to culture, oleh karena kehidupan modern saat ini banyak menimbulkan krisis dalam banyak bidang (Assegaf, 2011: 193).

Perenialisme mengambil jalan regresif karena mempunyai pandangan bahwa tidak ada jalan lain kecuali kembali kepada prinsip umum yang telah menjadi dasar tingkah laku dan perbuatan zaman Yunani Kuno dan abad pertengahan. Yang dimaksud dengan ini adalah kepercayaankepercayaan aksiomatis mengenai pengetahuan, realitas, dan nilai dari zaman tersebut (Assegaf, 2011: 193).

Perenialisme dapat dikenali dengan mudah karena memiliki kekhasan, diantaranya adalah: pertama, bahwa perenialisme mengambil jalan 
regresif, yaitu kembali kepada nilai dan prinsip dasar yang menjiwai pendidikan pada masa Yunani Kuno dan Abad Pertengahan. Kedua, perenialisme beranggapan bahwa realita itu mengandung tujuan. Ketiga, perenialisme beranggapan bahwa belajar adalah latihan dan disiplin mental. Keempat, perenialisme beranggapan bahwa kenyataan tertinggi itu berada di balik alam, penuh kedamaian, dan transcendental (Assegaf, 2011: 193-194).

Perenialisme, sesuai dengan namanya yang berarti segala sesuatu yang ada sepanjang sejarah, melihat bahwa teradisi perkembangan intelektual yang ada pada zaman yunani kuno dan abad pertengahan yang telah terbukti dapat memberikan solusi bagi berbagai problem kehidupan masyarakat perlu digunakan dan diterapkan dalam menghadapi alam modern yang sarat dengan problem kehidupan (Muhmidayeli, 2005: 173).

Kondisi dunia modern yang sangat mengandalkan rasionalitas empiris-positivistis yang memandang kebenaran dalam konteksnya yang serba terukur, teramati dan teruji secara inferesial yang melihat realitas sebagai sesuatu yang serba materi, telah pula memunculkan berbagai problem kemanusiaan, seperti munculnya sikap ambivalinsi yang mencengkam dan mendatangkan kebingungan, kebimbangan, kecemasan, ketakutan dalam bertingkah laku, sehingga manusia hidup dalam ketidak menentuan dan cendrung kehilangan arah dan jati dirinya. Pengabdian berpikir logis dalam hal ini telah pula memunculakan ketidakmampuan manusia melihat pengetahuan yang sebenarnya. Hal ini mengingat corak kehidupan yang serba rasional bertujuan dengan landasan empiris-positivistis yang melihat realitas dan fakta-fakta yang terverfikasi dan terukur secara ketat, telah pula menjadikan ilmu pengetahuan dan ternologi sebagai orentasi kehidupan (Muhmidayeli, 2005: 173-174).

\section{Dengan}

memperhatikan pengertian di atas dan latar belakang timbulnya prenialisme tersebut dapat kita pahami bahwa pada dasarnya aliran ini berasal dari pemikiran orangorang eropa yang berusaha untuk mencari jawaban akibat banyaknya ketimpangan, kekacauan, kebingungan, serta berbagai problematika lainnya. Mereka menganggap bahwa ide umum yang terkandung dalam pemikiran filosof zaman Yunani Kuno dan abad pertengahan itu adalah memiliki nilai yang ideal dan masih relevan untuk menjawab persoalan masa kini (Assegaf, 2011: 194).

Menurut Raghib al-Isfahani terdiri dari dua unsur, yakni tubuh dan jiwa. Bila tubuh dapat dikenal dengan indra mata, maka jiwa hanya dapat dikenal dengan akal. Jiwa itu sendiri sangat menentukan bagi tubuh. Selain dapat menciptakan kehidupan, ia juga dapat menggerakkan tubuh untuk bekarja, merasa, berilmu dan berfikir (Amril M., 2002: 142).

Dengan demikian bahwa aliran prenialisme ini menginginkan bahwa zaman terdahulu (lampau) tetap dipertahankan dan diabadikan. Sebab zaman modern banyak membawa kerusakan kepada manusia. Mereka juga beranggapan bahwa zaman modern ini suatu zaman yang sakit. Karna zaman modern ini menjadikan krisis diberbagai bidang. Baik itu tingkah laku manusia, kebiasaankebiasan yang tidak sesuai dengan budaya mereka yang terdahulu. Oleh karena itu aliran berinisiatif agar kembali kepada budaya yang lama dan ideal. Karna budaya yang lama dan 
ideal itu sesuai dengan prinsip hidup mereka.

\section{Dasar Filosofis Perenialisme}

Sebagaimana pada perkembagan pemikiran filsafat umumnya, dasar pemikiran filsafat perenialisme ini pun terlihat dari keyakinan ontologis mereka tentang manusia dan alam. Aliran ini memandang bahwa hakikat manusia sebagai makhluk rasional yang akan selalu sama bagi setiap manusia dimana pun dan sampai kapan pun dalam pengembangan historisitasnya. Keyakinan ontologis sedemikian, bahwa mereka pada suatu pemikiran, bahwa kemajuan dan keharmonisan yang dialami oleh manusia disuatu masa akan dapat pula diterapkan pada manusia-manusia lain pada masa dan tempat yang berbeda, sehingga kesuksesan masa lalu dapat pula diterapkan untuk memecahkan problem masa sekrang dan akan datang bahkan sampai kapan pun dan dimana pun (Muhmidayeli, 2005: 176).

Watak insan ialah luwes, lentur (flexible). Boleh dilentur, dibentuk dan diubah. Ia mampu untuk menguasai ilmu pengetahuan, menghayati dan sehat dengan adat-adat, nilai, tradisi atau aliran baru. Atau meninggalkan adat, nilai dan aliran lama, dengan cara intraksi sosial baik dengan lingkungan yang bersifat alam atau kebudayaan. Proses membentuk identitas, sifat dan watak atau mengubah dan memupuk serta mengajukan ciri-cirinya yang unik dinamakan sosialisasi, atau proses" pemasyarakatan." Mudah atau susahnya proses ini bergantung pada usia dan cara yang digunakan untuk sampai kepada tujuan (al-Syaibani, 1979: 156).

Menurut psikologi Plato, manusia pada hakikatnya memiiki tiga potensi dasar, yaitu nafsu, kemauan dan pikiran. Ketiga potensi ini merupakan asas bagi bangunan kepribadian dan watak manusia. Ketiga potensi ini akan tumbuh dan berkembang melalui pendidikan, sehingga ketiganya berjalan secara berimbang dan harmonis. Manusia yang memiliki potensi rasio yang besar akan manusia kelas pemimpin, kelas social yang tinggi. Manusia yang besar potensi kemauannya, akan menjadi manusiamanusia prajurit, kelas menengah. Sedangkan manusia yang besar potensi nafsunya akan menjadi manusiamanusia pekerja, kelas rakyat jelata. Pendidkan dalam hal ini hendaklah berorientasi pada potensi psikologis dan masyarakat, sehingga dapat mewujudkan pemenuhan kelas-kelas sosial dalam masyarakat tersebut (Muhmidayeli, 2005: 176).

Adapun jalan yang ditempuh adalah dengan cara regresif, yakni kembali kepada prinsip umum yang ideal yang dijadikan dasar tingkah pada zaman kuno dan abad pertengahan. Prinsip umum yang ideal itu berhubungan dengan nilai ilmu pengetahuan, realita, dan moral yang mempunyai peranan penting dan pemegang kunci bagi keberhasilan pembangunan kebudayaan pada abad ruang angkasa ini. Prinsip yang bersifat aksiomatis ini tidak terikat waktu dan tetap berlaku dalam perjalanan sejarah (Djumransjah, 2006: 187).

Hal yang sama juga diungkap Aristoteles yang mengatakan, bahwa kebahagiaan hidup sebagai tujuan pendidikan itu sendiri dapat terealisasi jika ketiga komponen potensi dasarnya terdidik dan berkembang secara seimbang. Harmonisasi fungsionalitas tiga potensi dasar manusia dalam aktifitasnya merupakan kunci bagi pengembangan kualitas humanitas manusia dalam kehidupannya. Oleh karena itu, pengisian pendidikan dalam ketiga asfek ini merupakan suatu keniscayaan. Pendidik bertugas memberikan bantuan kepada subjeksubjek didiknya untuk mewujudkan 
potensi-potensi yang ada padanya agar menjadi aktif, nyata dan aktual, melalui latihan berfikir secara baik dan benar. Pendeknya pembinaan dan latihan berfikir merupakan teori dasar dalam pembelajarannya, sehingga dengan demikian mental disiplin merupakan karakteristik pokok dalam teori belajar aliran perenialisme ini (Muhmidayeli, 2005: 177).

Aliran ini berkeyakinan, bahwa kendatipun dalam lingkungan dan tempat yang berbeda-beda, hakikat manusia tetap menunjukkan kesamaannya. Oleh karena itu, pola dan corak pendidikan yang sama dapat diterapkan kepada siapapun dan dimanapun ia berada. Menurutya, setiap manusia memiliki fungsi kemanusiaan yang sama, karena memang terlahir dari hakikat yang sama sebagai makhluk rasional. Aliran ini brpendapat, bahwa rasionalitas adalah hukum pertama yang tetap benar di segala waktu dan tempat. Dengan prinsip rasionalitas ini pula akan memunculkan adanya prinsip kesadara dan kebebasan. Aliran ini berkeyakinan bahwa dimanapun manusia tetap menunjukkan kesamaannya. Oleh karena itu pola pendidikan apapun yang diterapkan, kita sebagai manusia tetap akan menerima pendidikan itu. Karna kita terlahir sebagai makhluk rasional yang membedakan dengan makhluk lainnya. Tentunya dengan rasional yang dimiliki manusia akan menggiring manusia itu untuk dapat menggunakan rasio nya itu dengan baik dan terarah. Begitu juga rasional merupakan hukum yang pertama yang dimiliki manusia dan dapat dimanfaatkan dengan baik dan terarah.

\section{Pemikiran Perenialisme Tentang Pendidikan}

Filsafat perenialisme dalam pendidikan lahir pada abad ke-20. Perenialisme lahir dari suatu reaksi terhadap pendidikan progresif. Perenialisme menentang pandangan progresivisme yang menekankan perubahan dan sesuatu yang baru. Perenialisme memandang situasi dunia dewasa ini penuh kekacauan, ketidakpastian, terutama dalam kehidupan moral, intelektual, dan sosio-kultural. Solusi yang ditawarkan kaum perenialis adalah dengan jalan mundur ke belakang dengan menggunakan kembali nilai-nilai atau prinsip-prinsip umum yang telah menjadi pandangan hidup yang kukuh, kuat pada zaman kuno dan abad pertengahan. Peradaban-kuno (Yunani Purba) dan abad pertengahan dianggap sebagai dasar budaya bangsa-bangsa di dunia dari masa ke masa dan dari abad ke abad. Oleh karena itu, perenialisme memandang pendidikan sebagai jalan kembali atau proses mengembalikan keadaan manusia sekarang seperti dalam kebudayaan ideal yang dimaksud, education as cultural regression. Perenialisme tidak melihat jalan yang meyakinkan selain kembali kepada prinsip-prinsip yang telah sedemikian membentuk sikap kebiasaan, bahkan kepribadian manusia selain kebudayaan dahulu dan kebudayaan abad pertengahan. Perenialisme tidak memiliki kepercayaan diri bahwa zaman ini tidak akan berubah menjadi baik jika tidak kembali pada nilai-nilai budaya lama yang dianggapnya ideal dan sudah mapan (Ahmadi, 2014: 100-101).

Perenialisme percaya bahwa seseorang harus megajarkan hal-hal yang dianggap menjadi kemanfaatan abadi bagi semua orang di mana-mana. Mereka percaya bahwa topic yang paling penting adalah mengembangkan seseorang. Karena detail fakta berubah terus-menerus, ini tidak dapat menjadi 
yang paling penting. Oleh karena itu, seseorang harus mengajarkan prinsipprinsip bukan fakta. Karena orang adalah manusia, kita harus mengajarkan pertama tentang manusia, bukan mesin atau teknik. Jika semuaya demikian, seorang harus mengajarkan topik liberal, bukan topic-topik vokasiona (Ahmadi, 2014: 100-101).

Tentang pendidikan kaum Perenialisme memandang education as cultural regression : pendidikan sebagai jalan kembali, atau proses mengembalikan keadaan manusia sekarang seperti dalam kebudayaan masa lampau yang dianggap sebagai kebudayaan ideal. Tugas pendidikan adalah memberikan pengetahuan tentang nilai-nilai kebenaran yang pasti, absolut, dan abadi yang terdapat dalam kebudayaan masa lampau yang dipandang sebagai kebudayaan ideal tersebut.Sejalan dengan hal di atas, penganut Perenialisme percaya bahwa prinsipprinsip pendidikan juga bersifat universal dan abadi.

\begin{tabular}{lrr}
\multicolumn{1}{c}{ Robert } & M. & $\begin{array}{r}\text { Hutchins } \\
\text { mengemukakan }\end{array}$ \\
mengimplikasikan & & $\begin{array}{r}\text { pengajikan } \\
\text { pengajaran }\end{array}$
\end{tabular}
pengetahuan. Pengetahuan adalah kebenaran. Kebenaran di mana pun dan kapan pun adalah sama. Karena itu kapan pun dan di mana pun pendidikan adalah sama". Selain itu pendidikan dipandang sebagai suatu persiapan untuk hidup, bukan hidup itu sendiri (Zuhairini, 2008: 27).

Dalam hal pendidikan, perenialisme memandang bahwa tujuan utama pendidikan adalah untuk membantu siswa dalam memperoleh dan merealisasikan kebenaran abadi. Aliran ini menilai bahwa kebenaran itu bersifat universal dan konstan. Maka jalan untuk mencapainya adalah melatih intelek dandisiplin mental. Tujuan pendidikan tersebut terurai dalam format kurikulum yang berpusat pada materi (contend based, subjectcentered) dan mengutamakan disiplin ilmu sastra, matematika, bahasa, humaniora, sejarah dan lain-lain (Assegaf, 2011: 194-195).

Kelompok perenialisme misalnya, menyebebutkan pendidikan itu pada dasarnya meningkatkan kualitas manusia sebagai manusia dalam kerangka nilai-nilai kebenaran yang universal, tidak terikat oleh ruang dan waktu. Dengan demikian system pendidikan apapun dan di dalam masyarakat manapun mesti mengacu pada nilai-nilai kebenaran universal. Sedemikian rupa anak didik dalam pendidikan dibantu untuk menemukan dan menjalin nilai-nilai universal ini dalam kehidupan mereka (Knellr, 1972: 43).

Perenialisme memandang pendidikan sebagai jalan kembali atau proses pengembalian keadaan sekarang. Perenialisme memberikan sumbangan yang berpengaruh, baik berupa teori maupun praktik bagi kebudayaan dan pendidikan zaman sekarang. Maka, dapat dikatakan bahwa perenialisme memandang pendidikan sebagai jalan kembali, yaitu sebagai suatu proses mengembalikan kebudayaan sekarang (zaman modern atau modernistik) ini terutama pendidikan zaman sekarang ini perlu dikembalikan kebudayaan pada masa lampau (Gandhi HW, 2013: 165).

Perenialisme merupakan aliran filsafat yang medasarkan pada kesatuan, bukan mencerai-beraikan; menemukan persamaan-persamaan, bukan membanding-bandingkan; serta memahami isi, bukan melihat luar atas berbagai aliran dan pemikiran. Maka dari itu, dapat dikatakan bahwa perenialisme merupakan filsafat yang susunannya mempunyai kesatuan. Susunan tersebut merupakan hasil pikiran yang memberikan kemungkinan bagi seseorang untuk 
bersikap tegas dan lurus. Oleh karena itulah, perenialisme berpendapat bahwa mencari dan menemukan arah tujuan yang jelas merupakan tugas yang utama dari filsafat, khususnya filsafat pendidikan (Gandhi HW, 2013: 165).

Perenialisme sebagai sebuah aliran dalam filsafat pendidikan yang mendasari dirinya pada keyakinan bahwa pengetahuan sejatinya yang didapat melalui ruang dan waktu mestilalah membentuk dasar-dasar pendidikan seseorang. Oleh karena itu tugas pendidikan itu adalah mengajar, termasuk mengajar pengetahuan yang mana pengetahuan itu termasuk kebenaran. Kebenaran itu sendiri dimana-mana sama, sedemikian rupa menjadikan pendidikan itu dimana pun mestilah sama, sedangkan anak didik sebagai individu dipandang oleh kelompok ini adalah sebagai makhluk rasional dan spiritual. Secara implisit tentunya juga anak didik adalah makhluk moral dan etik (Amril M., 2005: 26-27).

Pendidikan menurut aliran ini bukanlah semacam imitasi kehidupan, tetapi tidak lain adalah suatu upaya mempersiapkan kehidupan. Sekolah menurut kelompok ini tidak akan pernah dapat menjadi situasi kehidupan yang ril. Anak dalam hal ini menyusun rancangan dimana ia belajar dengan prestasi-prestasi warisan budaya masa lalu. Tugasnya kemudian adalah bagaimana merealisasikan nilainilai yang diwariskan kepadanya dan jiika memunginkan meningkatkan dan menambah prestasi-prestasi itu melalui usaha sendiri (Muhmidayeli, 2005: 180).

Prinsip mendasar pendidikan bagi aliran perennial ini adalah membantu subjek-subjek didik menemukan dan menginternalisasikan kebenaran abadi, karena memang kebenarannya sifat universal dan tetap. Kebenarann- kebenaran seperti ini hanya dapat diperoleh subjek-subjek didik melalui latihan intelektual yang dapat menjadikan pikirannya teratur dan tersistematisasi sedemikian rupa. Hal ini semakin penting terutama jika dikaitkan dengan persoalan pengembangan spiritual manusia (Muhmidayeli, 2005: 180).

Aliran ini meyakini bahwa pendidikan adalah transfer ilmu pengetahuan tentang kebenaran abadi. Pengetahuan adalah suatu kebenaran sedangkan kebenaran selamanya memiliki kesamaan. Oleh karena itu pula maka penyelengaraan pendidikan pun di mana-mana mestilah sama. Pendidikan mestilah mencari pola agar subjek-subjek didik dapat menyesuaikan diri bukan pada dunia saja, tapi hendaklah pada hakikathakikat kebenaran. Penyesuaian diri pada kebenaran merupakan tujuan belajar itu sendiri. Oleh karena itu, para Perenialisme memandang, bahwa tuntutan tertinggi dalam belajar adalah latihan dan disiplin mental. Para Perenialis percaya, bahwa pemikiran subek-subjek didik akan menjadi nyata melalui pelatihan-pelatihan intelektual. Cara mudah untuk mengajar subjeksubjek didik adalah dengan cara menumbuhkan keinginan untuk belajar. Realisasi diri sangat tergantung pada disiplin diri, sedangkan disiplin diri itu sendiri dapat diraih melalui disiplin eksternal. Berdasarkan pemikiran ini, maka Perenialis sampai suatu kesimpulan, bahwa belajar adalah upaya keras untuk memperoleh sesuatu ilmu pengetahuan melalui disiplin tinggi dalam latihan pengembangan prinsip-prinsip rasional (Muhmidayeli, 2005: 180-181).

Keinginan untuk menjadi diri sendiri itu ada pada setiap manusia. Maka setiap anak yang berada dalam ikatan pendidikan dengan pendidikannya, adalah mereka yang 
pada dasarnya ingin menjadi "diri sendiri". Anak ingin menjadi individu yang bebas, dan untuk itu ia mempertahankan dirinya dengan sekelilingnya. Semangat kehidupan itu ada, namun merasa tak mampu bahkan pada saat dilahirkan sama sekali tidak berdaya (Sadulloh: 2010: 142-143).

Jadi epistemologi dari perenialisme, harus memiliki pengetahuan tentang pengertian dari kebenaran yang sesuai dengan realita hakiki, yang dibuktikan dengan kebenaran yang ada pada diri sendiri dengan menggunakan tenaga pada logika melalui hukum berpikir metode deduksi, yang merupakan metode filsafat yang menghasilkan kebenaran hakiki (Syam, 1998: 297). Menurut perenialisme penguasaan pengetahuan mengenai prinsip-prinsip pertama adalah modal bagi seseorang untuk mengembangkan pikiran dan kecerdasan. Dengan pengetahuan, bahan penerangan yang cukup, orang akan mampu mengenal faktor-faktor dengan pertautannya masing-masing memahami problema yang perlu diselesaikan dan berusaha untuk menggadakan penyelesaian masalahnya.

Makna hakiki dari belajar, menurut aliran ini, adalah belajar untuk berfikir. Aliran ini meyakini bahwa dengan cara latihan berfikir, subjek didik akan memiliki senjata ampuh dalam menghadapi berbagai rintangan yang akan menurunkan martabat kemanusiaannya, seperti kebodohan, kebingungan, dan keragu-raguan. Tugas seorang subjek didik menurut aliran ini adalah mempelajari berbagai karya dalam berbagai literatur filsafat, sejarah, dan sains, sehingga dengan demikian ia berkenalan dengan berbagai prestasi di masa lalu menuju pembentukan pemikiran yang akan mengisi kehidupannya dalam membangun prestaasi-prestasinya pula. Para subjek didik dalam hal ini mesti meraih subjek-subjek dasar tertentu yang akan mengajarkan kepadanya hal-hal yang permanen tentang dunia. Subjek-subjek dasar seperti bahasa, sejarah, matematika, pengetahuan alam, filsafat dan seni merupakan hal penting yang sangat berguna bagi mereka dalam mengembangkan pemikirannya, sehingga dengan demikian mereka pun memiliki kemampuan rasional yang kokoh dalam menghadapi tentangan realitas kehidupannya (Muhmidayeli, 2005: 181-182).

\section{TOKOH-TOKOH PERENIALISME Plato}

Plato dilahirkan di Athena pada tahun 427 SM. dan meninggal pada tahun 347 SM. dalam usia 80 tahun. Ia dibesarkan dalam keluarga bangsawan Athena yang kaya raya, sebuah keluarga Aristokrasi yang turun temurun memegang peranan penting dalam politik Athena (Hata, 1986: 80). Ayahnya Ariston mengaku keturunan raja Athena, ibu Plato, Periction, adalah keturunan keluarga Solon. seorang pembuat undang-undang, penyair, pemimpin militer dari kaum ningrat dan pendiri demokrasi Athena yang terkemuka (Smith, 1986: 29). Plato adalah filsuf idealis, ia memandang dunia ide sebagai dunia kenyataan. Pokok pikiran plato tentang ilmu pengetahuan dan nilai-nilai adalah manifestasi daripada hukum universal yang abadi dan sempurna. Yakni idea, sehingga ketertiban sosial hanya akan mungkin bila ide itu menjadi ukuran, asas normatif dalam tata pemerintahan. Maka tujuan pendidikan adalah "membina pemimpin yang sadar" dan mempraktekkan asas-asas normatif itu dalam semua aspek kehidupan.

Prinsip-prinsip Plato dalam Pendidikan nampak pada pemikirannya 
tentang tujuan hidup adalah untuk mencari kebenaran universal. Sehingga tujuan pendidikan adalah mengembangkan daya pikiran individu yang bermuara pada penemuan kebenaran bukan ketrampilan praktis. Pemikiran ini muncul karena Plato tidak sejalan dengan mayoritas kaum sophis pada waktu yang -menganggap pengajaran pada mahasiswa kurang tepat (Smith, 1986: 29).

Menurut Plato, manusia secara kodrati memilki tiga potensi, yaitu nafsu, kemauan dan pikiran. Pendidikan hendaknya berorientasi pada tiga potensi itu dan juga kepada masyarakat. Agar supaya kebutuhan yang ada pada masyarakat dapat terpenuhi. Ketiga potensi ini merupakan dasar kepribadian manusia. Karena itu struktur sosial didasarkan atas dasar pandangan kepribadian ini. Dengan pertimbangan ketiga potensi itu tidak sama pada setiap individu, berikut penjelasannya: (a) Manusia yang besar potensi rasionya, inilah manusia kelas pemimpin kelas sosial tertinggi; (b) Manusia yang dominan potensi kemauannya, ialah manusia prajurit, kelas menengah; dan (c) Manusia yang dominan potensi nafsunya, ialah rakyat jelata, kaum Pekerja (Syam, 1998: 321).

\section{Aristoteles}

Aristoteles lahir di Stageira ,suatu kota kecil di semenanjung Kalkidike di Trasia (Balka) pada tahun 384 SM dan meninggal di Kalkis pada tahun 322 SM. Bapaknya bernama Nichomachus, seorang dokter istana yang merawat Amyintas II raja Macedonia (Smith, 1986: 35). Sejak kecil ia mendapat asuhan dan keilmuan langsung dari ayahnya sendiri sampai berumur 18 tahun. Setelah ayahnya meninggal ia pergi ke Athena dan belajar pada Plato di Akademia selama 20 tahun. Ide-ide
Plato dikembangkan oleh Aristoteles dengan lebih mendekatkan pada dunia kenyataan. Aristoteles terutama menitikberatkan pembinaan berfikir melaluyi media sciences. Pandangan Aristoteles lebih realis dari pandangan Plato, hal ini dikarenakan cara belajar kepada ayahnya yang lebih menekankan pada metode pengamatan. Aristoteles menganggap pembinaan kebiasaan sebagai dasar. Terutama dalam pembinaan kesadaran disiplin atau moral, harus melalui proses permulaan dengan kebiasaan di waktu muda. Secara ontologis, ia menyatakan bahwa sifat atau watak anak lebih banyak potensialitas sedang guru lebih banyak mempunyai aktualitas. Bagi aristoteles tujuan pendidikan adalah kebahagiaan. Untuk mencapai tujuan pendidikan itu, maka aspek jasmani, emosi dan intelek harus dikembangkan secara seimbang (Hadiwijono, 1986: 104).

\section{Augustino Steuco}

Augustino Steuco lahir di kota pegunungan Umbrian di daerah Gubbio antara tahun 1497 atau awal kelahirannya tahun 1512 atau 1513 dan menetap hingga tahun 1517. Selanjutnya pada tahun 1518-1552 sebagian waktunya digunakan untuk mengikuti perkuliahan di Universitas Bologna. Di situlah ia mulai tertarik pada bidang bahasa dengan banyak belajar bahasa Aram, Syiria, Arab dan Etiopia disamping bahasa Yunani.

Steuco adalah sarjana al Kitab dan seorang teolog. Dalam banyak hal ia mewakili sayap liberal teolog Katolik dan studi skriptual abad XVI. Karyakarya seperti Cosmopedia (1545) dan De Perenni Philosophia jelas menunjukkan pandangan yang liberal, yang mencoba untuk mensejajarkan antara berbagai tradisi filsafat pagan dengan tradisi ortodoks, akan tetapi 
disisi lain pandangan konservatifnya juga tetap tampak dengan ketegarannya menolak ajaran Calvin, terutama Martin Luther. Steuco menganggap ajaran tradisi agamaagama pagan dan non Kristen lebih dapat diterima daripada ajaran pada pembaharu, Lutherianisme.

Karya paling termasyhur dari Steuco adalah De Perenni Philosophia, karya yang mendapat sambutan hangat dikalangan pemikir hingga dua abad kemudian. Pada abad XVI buku tersebut mendapat penghargaan yang sedemikian tinggi sehingga Kaspevon Barth (1587-1658) menyebutnya sebagai "A Golden Book" dan Daniel George Marhof (1639-1691) merujuknya sebagai "Opus Admirable" namun kemasyhuran itu berangsurangsur mulai dilupakan hingga kemudian Willman menemukannya kembali pada akhir abad XIX.

Kunci pemikiran filsafat Steuco terlihat pada pandangannya bahwa terdapat "prinsip tunggal dari segala sesuatu" yang satu dan selalu sama dalam pengetahuan manusia. Menurut Steuco agama merupakan kemampuan alamiah manusia untuk mencapai kesejatian. Agama merupakan syarat mutlak bagi manusia untuk menjadi manusia, dan merupakan vera philosophia (fisafat sejati), yaitu filasafat yang mengarah kepada kesalehan dan kontemplasi pada Tuhan. Filsafat dan agama yang sejati selalu mendorong untuk menjadi subyek Tuhan melakukan apa yang Tuhan inginkan dan meninggalkan apa yang dilarang-Nya, hingga menjadi "seperti" Tuhan.

\section{Thomas Aquinas}

Thomas Aquinas atau Tomas dari Aquino (1224-1274 M) lahir di Rocca Sicca dekat Napels, Italia. Lahir dari sebuah keluarga bangsawan. Ia mempelajari karya-karya besar Aritoteles dan ikut serta dalam berbagai perbedaan. Thomas merupakan seorang tokoh yang sebagian ajarannya menjadi penuntun perenialisme (Barnadib, 1997: 63). aryanya yang utama adalah Suma Contra Gentiles dan Summa Theologiae (Tafsir, 2005: 98).

Seperti halnya Plato dan Aristoteles tujuan pendidikan yang diinginkan oleh Thomas Aquinas adalah sebagai "usaha mewujudkan kapasitas yang ada dalam individu agar menjadi aktualitas" aktif dan nyata. Tingkat aktif dan nyata yang timbul ini bergantung dari kesadaran-kesadaran yang dimiliki oleh tiap-tiap individu. Dalam hal ini peranan guru mengajar dan member bantuan pada anak didik untuk mengembangkan potensi-potensi yang ada padanya.

Aquinas juga mengakui potensi martabat manusia sebagai makhluk intelek sekaligus sebagai makhlik susila. Manusia dapar melakukan reflektif thinking tetapi juga manusia tak mungkin menolak dogma sebagai divine truth yang tidak rasional, melainkan supernasional.

\section{Sayyed Hossein Nasr}

Sayyed Hossein Nasr adalah seorang filsuf dan mistikus yang dilahirkan pada tahun 1933 di Teheran, ia dikenal sebagai salah satu cendekiawan muslim yang mempunyai wawasan sangat kaya tantang khasanah islam. Karyanya yang sangat terkenal adalah "Science and Civilization in islam", sebuah buku yang diangkat dari disertasinya tentang sejarah sains. Nasr mengatakan bahwa filsafat perenial adalah pengetahuan yang selalu ada dan akan ada yang bersifat universal. "Ada" yang dimaksud adalah berada pada setiap jaman dan setiap jaman dan 
setiap tempat karena prinsipnya yang universal. Pengetahuan yang diperoleh melalui intelektualitas ini terdapat dalam inti semua agama dan tradisi. Realisasi dan pencapaiannya hanya mungkin dilakukan melalui metodemetode, ritus-ritus, simbol-simbol, gambar-gambar dan sarana-sarana lain yang disucikan oleh asal ilahiah atau (divine original) yang menciptakan setiap tradisi.

Ketertarikannya kepada tradisi mulai muncul, ketika ia bertemu sejarawan sains Giogio de Santillana, yang kemudian memperkenalkannya kepada literatur tentang Hinduisme karya Rene Guenon. Dari Guenon, jalan ke para tradisionalis lain terbuka: Coomaraswamy, Schuon, dan sebagainya.

Di Taheran ia menjumpai fukaha yang menganggap filsafat sebagai ilmu kafir. Di saat inilah ia memutuskan untuk belajar ilmu-ilmu tradisional Islam di madrasah. Ia menjalani pendidikan ini selama 10 tahun, di bawah bimbingan beberapa ulama terkenal, di antaranya Allamah Thabathaba'i. Hingga tahun 1978, belasan buku ditulisnya. Di antaranya yang telah diterjemahkan ke bahasa Indonesia adalah Sains dan Peradaban dalam Islam, Tiga Pemikir Islam, dan Tasawuf Dulu dan Sekarang.

Dalam masa 20 tahun, karirnya pun menanjak cepat. Buku-buku monumental seperti 2 jilid Islamic Spirituality dan History of Islamic Philosophy, serta ratusan artikel lain telah ditulisnya. Tak ketinggalan adalah kaset dan CD pembacaan puisi-puisi Rumi. Hingga akhirnya, puncak pengakuan akan capaian filsafat Profesor Kajian Islam di Universitas GeorgeWashington ini diperolehnya sebagai tokoh dalam The Library of Living Philosophers.

Tokoh-tokoh yang disebut diatas adalah tokoh-tokoh yang memiliki corak pemikiran sejalan dengan filsafat perenial atau perenialisme. Sebagaimana yang telah dijelaskan sebelumnya bahwa Perenialisme bukan merupakan suatu aliran baru dalam filsafat, dalam arti perenialisme bukanlah merupakan suatu bangunan pengetahuan yang menyususn filsafat baru, yang berbeda dengan filsafat yang telah ada.

Secara maknawi teori perenialisme sudah ada sejak zaman filosof abad kuno dan pertengahan. Seperti halnya dalam bidang pendidikan, konsep perenialisme dalam pendidikan dilatar belakangi oleh filsafat-filsafat Plato sebagai bapak idealisme klasik, filsafat Aristoteles sebagai bapak realism klasik, dan filsafat Thomas Aquinas yang mencoba memadukan antara filsafatAristoteles dengan ajaran (filsafat) Gereja Katolik yang tumbuh pada zamannya (abad pertengahan).

\section{SIMPULAN}

Esensi aliran ini berupaya menerapkan nilai-nilai atau normanorma yang bersifat kekal dan abadi yang selalu seperti itu sepanjang sejarah manusia, maka prenialisme dianggap sebagai suatu aliran yang ingin kembali atau mundur kepada nilai-nilai kebudayaan masa lampau. Kembali kepada masa lampau dalam konteks aliran ini, bukanlah dalam pengertian bernostalgia dan sekedar mengingat-ingat kembali pola kehidupan masa lalu,tetapi untuk membina kembali keyakinan akan nilainilai asasi masa silam untuk menghadapi problema kehidupan manusia saat sekarang dan bahkan sampai kapan pun dan di mana pun. Dengan demikian maka prenialisme ini menginginkan bahwa budaya, adat istiadat-istiadat yang terbiasa mereka lakukan merupakan suatu yang abadi, kekal tanpa akhir. 


\section{DAFTAR RUJUKAN}

Ahmadi, Rulam. 2014. Pengantar Pendidikan Asas \& Filsafat Pendidikan. Yogyakarta: Ar-Ruz Media.

al-Syaibani, Omar Mohammad alToumy. 1979. Falsafah Pendidikan Islam. Jakarta: Bulan Bintang.

Assegaf, Abd. Rahman. 2011. Filsafat pendidikan Islam, Cet. II. Jakarta: RajaGrafindo Persada.

Barnadib, Imam. 1997. Filsafat Pendidikan Sistem dan Metode.

Yogyakarta: Andi Offset.

Djumransjah. 2006. Filsafat Pendidikan. Malang: Bayu Media.

H.W.,Teguh Wangsa Gandhi. 2013. Filsafat Pendidikan: MazhabMazhab Filsafat Pendidikan. Yogjakarta: Ar-Ruz Media.

Hadiwijono, Harun. 1989. Sari Sejarah Filsafat Barat . Yogyakarta: Kanisius.

Hata, Mohammad. 1986. Alam Pikiran Yunani. Jakarta: UI Press.

Knellr, George F., 1972. Introduction to The Philosophy of Education. New York: Jhon Wiley \& Sons, Inc.

M., Amril. 2002. Etika Islam Telaah Pemikiran Moral Raghib alIsfahani. Pekanbaru: LSFK2P.
2005. Etika dan Pendidikan.

Pekanbaru: LSFK2P.

Muhmidayeli. 2005. Filsafat Pendidikan Islam. Pekanbaru: LSFK2P.

Sadulloh, Uyoh. 2010. Pedagogik (Ilmu Mendidik). Bandung: Alfabeta.

Smith, Samuel. 1986. Gagasan-Gagasan Besar Tokoh-Tokoh Dalam Bidang Pendidikan. Jakarta: Bumi Aksara.

Syam, Muhammad Nur. 1986. Filsafat Pendidikan dan Dasar Filsafat Pancasila. Surabaya: Usaha Nasional.

Syam, Mohammad Noor. 1998. Filsafat Kependidikan dan Filsafat Kependidikan Pancasila. Surabaya: Usaha Nasional.

Tafsir, Ahmad. 2005. Filsafat Umum, Akal dan Hati Sejak Thales Sampai Capra. Bandung: Remaja Rosdakarya.

Zainal Abidin Bagir, Philosophia Perennis Menurut Hosein Nasr di akses 9 Juli 2009

http://ecfunpar.multiply.com/jou rnal/item $/ 3$

Zuhairini. 2008. Filsafat pendidikan Islam. Jakarta: Bumi Aksara. 